\title{
SOYBEAN PERFORMANCE AND CANONIC INTER-RELATIONS TOWARDS SPACING BETWEEN SOWING LINES
}

\author{
Evaldo Cervieri Filho ${ }^{1}$, Géri Eduardo Meneghelloํㅜㄹ Francisco Amaral Villela ${ }^{1}$, Ivan Ricardo \\ Ricardo Carvalho², Francine Lautenchleger ${ }^{3}$, Natã Balssan Moura ${ }^{2}$ \\ ${ }^{1}$ Federal University of Pelotas, Capão do Leão, Rio Grande do Sul State, Brazil \\ E-mails: filho@gmail.com,gmeneghello@gmail.com, francisco.villela@ufpel.edu.br, carvalho.irc@gmail.com \\ ${ }^{2}$ Northwestern Regional University of the State of Rio Grande do Sul, Ijuí, Rio Grande do Sul State, Brazil \\ E-mail:francinelautenchleger@ hotmail.com \\ ${ }^{3}$ University of the Midwest (Unicentro), Guarapuava, Paraná State, Brazil \\ E-mail: nata-moura@hotmail.com
}

\begin{abstract}
The aim of the study was to evaluate soybean performance and canonical interrelationships towards spacing between sowing lines. This study was developed in the 2019/2020 crop season, in the county of Lagoa da Confusão, Tocantins State, Brazil. The experimental design used was randomized blocks with four replications, using five spacing between lines (45, 35, 25 21, and 17 centimeters), conserving the same plant population. The plots consisted of four lines ten meters long. There was $30 \mathrm{~cm}$ between rows, demonstrating that it is attractive for soybean sowing. It should be noted that the reduction in the spacing of the sowing line leads to an increase in costs and operating time, which can make this recommendation unfeasible. With the objective of carrying out two consecutive plantings in the rainy season, it causes the rural producer to neglect some agronomic practices that increase productivity, especially when they result from increased operational time.
\end{abstract}

Keywords: Glycine max, plant arrangement, soy architecture

\section{DESEMPENHO DA SOJA E INTER-RELAÇÕES CANÔNICAS PARA O ESPAÇO ENTRE LINHAS DE SEMEADURA}

\section{RESUMO}

Objetivou-se com este estudo avaliar o desempenho da soja e as inter-relações canônicas no espaçamento entre linhas de semeadura. Este estudo foi desenvolvido na safra 2019/2020, no município de Lagoa da Confusão-TO. O delineamento experimental utilizado foi em blocos casualizados com quatro repetições, utilizando cinco espaçamentos entre linhas (45, 35, 2521 e 17 centímetros), conservando a mesma população de plantas. As parcelas foram compostas por quatro 
linhas de dez metros de extensão. O arranjo ótimo foi de $30 \mathrm{~cm}$ entre linhas, demonstrando que é atraente para a semeadura da soja. Para tanto, deve-se destacar que a redução do espaçamento da linha de semeadura acarreta aumento dos custos e tempo de operação, o que pode inviabilizar esta recomendação. Com o objetivo de realizar duas semeaduras consecutivas no período das águas, faz com que o produtor rural negligencie algumas práticas agronômicas que aumentam a produtividade, principalmente quando decorrem do aumento do tempo operacional.

Palavras-chave: Glycine max, arranjo de plantas, arquitetura da soja

\section{INTRODUCTION}

The growing of soybeans (Glycine max L.) is of great importance in the world economy due to its widespread use in human and animal food, through oil, feed, bran and also biofuels. In this way, the crop is grown in almost all parts of the world (SANTOS et al., 2018). Over the years, Brazilian soybean has undergone several changes with the emergence and use of new technologies such as direct sowing system, transgenic cultivars, the introduction of more productive cultivars, and also the use of biotechnological events (FERRARI et al., 2014; BALBINOT et al., 2016). Due to the socioeconomic importance of the crop for the country, several adjustments occurred in its production system (ROCHA et al., 2018). Recently, some growers, aiming at increasing productivity, have opted for densely planted soybean crops, using, for example, different spacing between lines (FOLLMANN et al., 2014; PETTER et al., 2016).

In face of the new cultivars and growing technologies, it is necessary to study management actions that can reflect on increased productivity, without major changes in production costs (BALBINOT JUNIOR et al., 2016). The greatest expression of the productive potential of cultivars, however, depends on the conditions of the environment where the plants will grow (CARVALHO et al., 2015; SANTOS et al., 2018). Several studies have already been carried out on the dynamics of soybean growing on strategies for raising yield levels with different plant arrangements in the field, such as the analysis of soybean growth and agronomic performance at different densities (PETTER et al., 2016), Rocha et al., (2018). Other studies conducted by Szareski et al., (2015); Balbinot et al., (2016), evaluated the growth of two soybean cultivars with determinate and indeterminate growth type, submitted to different spatial arrangements of plants, including cross-sowing. 
Studies carried out by Cruz et al. (2016) report the sowing of soybeans with double lines causes alteration of the plant architecture, reducing mainly its height. According to Camicia et al. (2018), the modification of spacing in cultivars with greater plasticity, may not influence the final yield of the crop, when the spacing is greater than recommended. The use of different sowing densities and spacing are important practices that can provide better use of the resources available for growth and grain yield (SILVA et al., 2015; SANTOS et al., 2018). In addition to influencing the speed of closing the between lines, incidence of invasive plants, penetration of agrochemicals in the lower canopy. The work aimed to evaluate the performance of soybean and the canonical interrelationships in the spacing between sowing lines.

\section{MATERIAL AND METHODS}

This study was developed in the 2019/2020 crop season, in the county of Lagoa da Confusão, Tocantins State, Brazil. The soils present in the region are Plinthosols and Gleysols, the climate is humid with moderate water deficiency in winter, average annual rainfall of $1.750 \mathrm{~mm}$, and cerrado is the predominant biome. Sowing was carried out in the first half of May and harvesting in the second half of August. The soybean cultivar 8473RSF was used, with base fertilization of $150 \mathrm{~kg}$ phosphate fertilization (MAP) in the row and top dressing of $150 \mathrm{~kg}$ of potassium chloride $(\mathrm{KCl})$ until 30 days after sowing.

The cultural practices performed in the experiment were the pre-sowing desiccation performed with Glyphosate (2.5 1 ha-1) and 2-4D (1.2 1 ha-1) and sequential Paraquat (2 1 ha-1). Seed treatment was carried out with Fludioxonil $(0.21 / 100 \mathrm{~kg})$ and Fipronil $(0.21 / 100 \mathrm{~kg})$. The post-sowing desiccation was carried out with Glyphosate (2.1 ha-1). Three fungicide applications were carried out, the first using the chemical group Stubirulins and Triazoles (0.4 1 ha-1), the second with the chemical group Carboxamides, Stubirulins and Triazolithione (0.5 1 ha-1) added Mancozeb (1 kg ha-1) and the third with the chemical group of Morpholins (0.3 1 ha-1) added with a Triazole (0.3 1 ha-1). Two applications of insecticides were carried out, one from the chemical group Chloranthraniliprol (0.07 1 ha-1) and the second application with the chemical group Neonicotinoid and Pyrethroid (0.2 1 ha-1).

The experimental design used was randomized blocks with four replications, using five spacing between lines $(45,35,25,21$, and 17 centimeters), conserving the same plant population per area, with four replications. The plots consisted of four lines ten meters long, totaling $20 \mathrm{~m}^{2}$, 
population of 10 plants by meter linear. The number of plants in each plot, plant height and first pod insertion height, number of pods per plant, number of pods with one, two, three or four seeds, number of seeds per plant, and the seed weight per plant were evaluated.

The experiment data were submitted to model assumptions, normality and homogeneity of residual variances and additivity of the statistical model. Then, the analysis of variance at 5\% probability was performed to identify the variations attributed to the different effects on soybean sowing spacing. The characters that differed statistically were used the linear regression of the highest significant degree of the polynomial by the $\mathrm{T}$ test at $5 \%$ probability. It was performed using the second degree equation $y=a \pm b x \pm c x^{2}$ applied to the formula of maximum technical

efficiency by the equation: MTE: $\frac{X^{1}}{2 \cdot\left(X^{2}\right)}$. Due to the diverse characters involved in the study, multivariate tools such as canonical correlations were applied to define the interrelationships between number and seed mass per plant (NSP and SMP) $\mathrm{x}$ first pod insertion height (FPI), plant height $(\mathrm{PH})$, number of pods per plant (NPP), number of pods with one grain (NP1), number of pods with two grains (NP2), number of pods with three grains (NP3), and number of pods with four grains (NP4). The statistical software used in the analyzes was GENES (CRUZ, 2013).

\section{RESULTS AND DISCUSSION}

The normality and homogeneity of the residual variances and additivity of the statistical model were identified for all variables measured in the experiment, these random variables being considered continuous with distribution tending to normal. The analysis of variance revealed significance for all the characters described (Table 1) with a magnitude of $1 \%$ probability. As well as in works carried out by Santos et al., (2018), Petter et al., (2016) and Werner et al., (2016) and disagreeing with Werner et al., (2020) who did not find a triple interaction between the factors studied (cultivars $\mathrm{x}$ densities $\mathrm{x}$ spacing) for all variables evaluated in two consecutive seasons.

The significance proposes that there were changes in the averages according to the change in line spacing and the high coefficients of variation mainly listed in the number of pods with one grain (NP1), number of pods with two grains (NP2), number of pods with three grains (NP3) and number of pods with four grains (NP4), are common due to the high heterogeneity of these averages in the field, in response to the genetic factor, which was probably elevated by the change in the plant arrangement caused by the different spacing between rows. 
The regression curves were expressed with normal quadratic effect for regression analysis in the characters of first pod insertion height (FPI) and plant height, in these obtained the maximum points in the order of 12.02 and $50.03 \mathrm{~cm}$ in the spacing between lines of 32.74 and $34.54 \mathrm{~cm}$, respectively (Figure 1A and B). The first pod insertion height is well adjusted because it is estimated that it must be within the limit of 10 to $15 \mathrm{~cm}$ to facilitate mechanical harvesting, since the plant height is very low when we think of high productive ceilings correlated to the morphological performance of soybean plants, where it should be between 80 to $120 \mathrm{~cm}$, it is logical that there are several factors that involve this character from the genotype to the environment.

Results found by Balbinot Junior et al., (2016) the best condition for increasing plant height was obtained with a $60 \mathrm{~cm}$ spacing and a density of 375 thousand seeds per hectare, probably because this cultivar has a high branching capacity and occupation of spaces between lines. In studies carried out by Cruz et al., (2016) and Werner et al., (2016), demonstrate that the plant height and the first insertion of the pod per plant, presented linear growth according to the increase in sowing density.In the other parameters evaluated, a quadratic effect was also characterized, but with an inverted parabola. Therefore, the minimum points for the characters of number of pods per plant (NPP), number of seeds per plant (NSP) and seed mass per plant (SMP) were in the order of $32.43,32.19$ and $34.96 \mathrm{~cm}$, corresponding to averages of 16.02 units, 37.54 units and $8.31 \mathrm{~g}$, respectively (Figure $\mathrm{C}, \mathrm{H}$ and I). The number of pods per plant is at the lower threshold of the average proposed by the commercial genotypes, since it is estimated that the plant has at least 30 pods per plant and that the pods have an average of grains that is usually between 2 to 2.5 grains per pod, which shows the low average of seeds per plant found in this study. Results found by Cruz et al. (2016) confirmed a decreasing linear effect for the number of pods per plant, due to the increase in sowing density. For Petter et al. (2016) the higher accumulation of dry mass in the higher densities is associated with the higher number of plants per area, and not necessarily with the higher production of photoassimilates.

The variation of grains by pods as a function of the spacing between the lines showed similar points of convergence. In this way, a series of plants was drawn with an average of 1.59 pods with one grain in the spacing of $33.87 \mathrm{~cm}$ (Figure 1D); 6 pods with two grains in the spacing of $32.26 \mathrm{~cm}$ (Figure 1E); 7.66 pods with three grains in the spacing of $32 \mathrm{~cm}$ (Figure 1F); and 0.6 pods with four grains in the spacing of $29.67 \mathrm{~cm}$ (Figure 1G). 

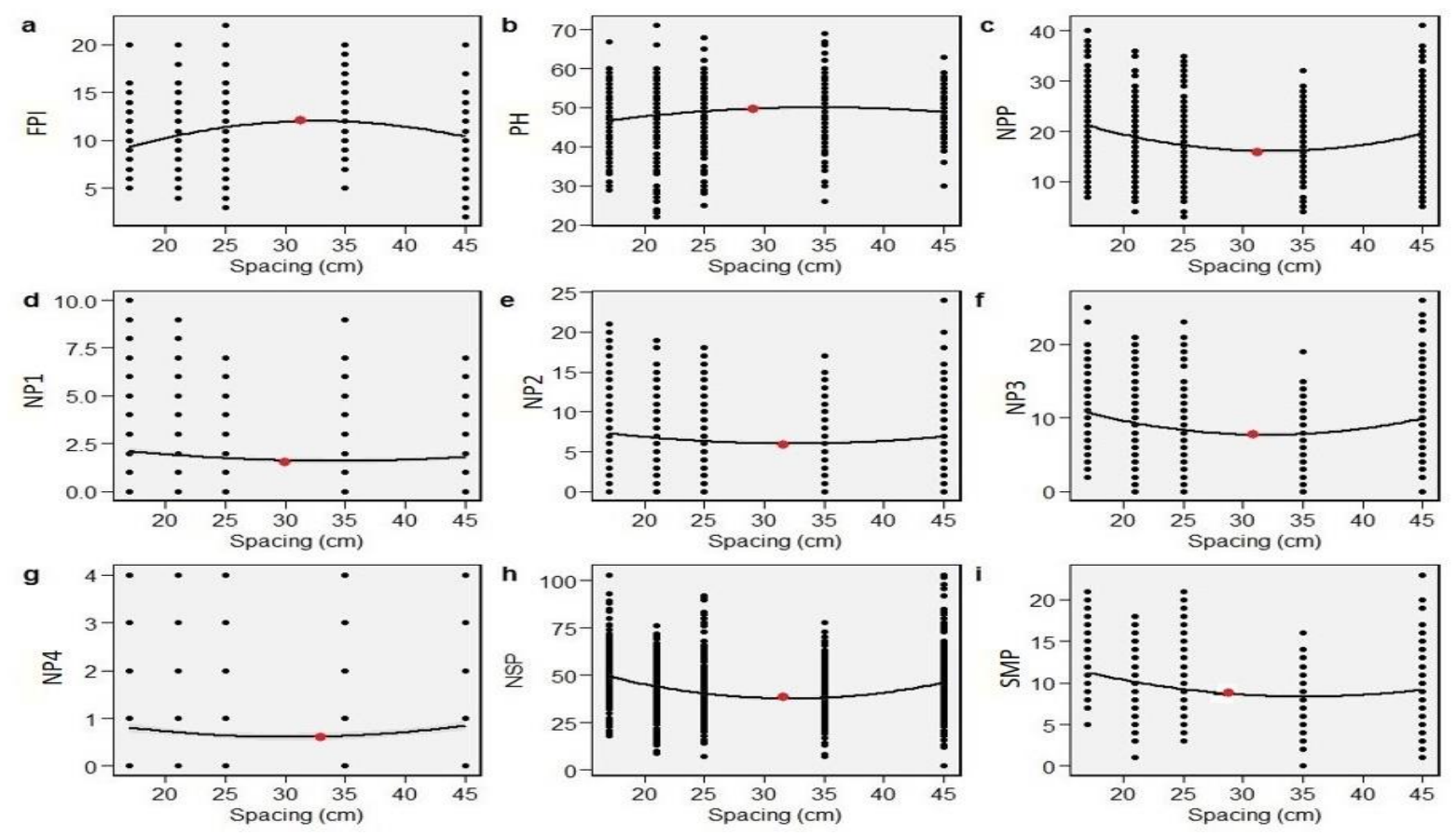

Figure 1. Linear regression for the variables: first pod insertion height (FPI), plant height (PH), number of pods per plant (NPP), number of pods with one, two, three and four grains (NP1, NP2, NP3, NP4), number of seeds per plant (NSP), seed mass per plant (SMP). Red dot corresponds to (MTE) Lagoa da Confusão - Tocantins State, Brazil, 2019.

Therefore, the plant density significantly alters the structure of the soybean canopy (WERNER et al., 2016), then varying the number of grains per pod. The maximum technical efficiency (MTE) was also analyzed (Figure 1), showing the minimum spacing that promotes the best minimum performance for each variable. Contributions to canonical correlations revealed that the increase in the mean number of seeds and dry mass of seeds per plant is positively correlated with the increase in the explanatory characters of pods per plant, pods with two grains, pods with three grains and pods with four grains, regardless of the spacing between sowing lines (Table 2). Positive correlations of yield components as a function of morphological components were also reported by Santos et al. (2018), as well as, the line spacing of $0.70 \mathrm{~m}$, the density of 15 plants $\mathrm{m}^{-1}$ provided the highest yields in soybean crop (CAMICIA et al., 2018).

First pod insertion height and number of pods with one seed little explained the agronomic characters, while the elevation of the plant height also explained the elevation of the characters in Group 1, with the exception of the plants that were submitted to spacing of $45 \mathrm{~cm}$ between lines, when the character lost its potential for explanation ( $r>0.1)$ (Table 3). 
Table 1. Summary of analysis of variances for first pod insertion height (FPI); plant height (PH); number of pods per plant (NPP); number of pods with one grain (NP1); number of pods with two grains (NP2); number of pods with three grains (NP3); number of pods with four grains (NP4), number of seeds per plant (NSP) and seed mass per plant (SMP). Lagoa da Confusão - Tocantins State, Brazil, 2019.

\begin{tabular}{|c|c|c|c|c|c|c|c|c|c|c|}
\hline $\mathrm{SV}$ & $\mathrm{DF}$ & FPI & $\mathrm{PH}$ & NPP & NP1 & NP2 & NP3 & NP4 & NSP & SMP \\
\hline Spacing & 4 & $253.02 * *$ & $376.31 * *$ & $1090.37 * *$ & $11.35 * *$ & $131.19 * *$ & $344.33 * *$ & $4.75 * *$ & $6379.71 * *$ & $354.21 * *$ \\
\hline Blocks & 3 & 605.40 & 4842.95 & 296.989 & 17.68 & 367.76 & 97.58 & 9.44 & 884.51 & 408.55 \\
\hline Residue & 12 & 7.25 & 35.69 & 29.96 & 2.62 & 10.42 & 14.64 & 0.97 & 188.28 & 9.04 \\
\hline $\mathrm{CV}(\%)$ & & 24.86 & 12.27 & 29.86 & 90.12 & 49.15 & 42.18 & 135.07 & 31.87 & 31.67 \\
\hline
\end{tabular}

** significant at $1 \%$ probability by the $\mathrm{F}$ test.

Table 2. Regression analysis for the characters first pod insertion height (FPI); plant height (PH); number of pods per plant (NPP); number of pods with one grain (NP1); number of pods with two grains (NP2); number of pods with three grains (NP3); number of pods with four grains (NP4), number of seeds per plant (NSP) and seed mass per plant (SMP) as a function of the spacing between sowing lines for soybean growing. Lagoa da Confusão - Tocantins State, Brazil, 2019.

\begin{tabular}{cccc}
\hline Characters & Mathematical model & $\mathrm{R}^{2}$ & MTE \\
\hline FPI & $0.3779936368+0.7110407693 \mathrm{x}^{* *}-0.0108598995 \mathrm{x}^{2 * *}$ & 0.78 & 0.31 \\
PH & $36.97703229+0.75442922 \mathrm{x} *-0.01092184 \mathrm{x}^{2 * *}$ & 0.23 & 0.29 \\
NPP & $38.71012645-1.39911598 \mathrm{x} *+0.02157147 \mathrm{x}^{2 * *}$ & 0.78 & 0.31 \\
NP1 & $3.670036897-0.123084560 \mathrm{x} *+0.001816990 \mathrm{x} \mathrm{x}^{2 * *}$ & 0.89 & 0.30 \\
NP2 & $11.56553061-0.34494455 \mathrm{x} *+0.00534714 \mathrm{x}^{2 * *}$ & 0.13 & 0.31 \\
NP3 & $21.44149197-0.86129686 \mathrm{x} *+0.01345814 \mathrm{x}^{2 * *}$ & 0.62 & 0.31 \\
NP4 & $1.747980110-0.077373499 \mathrm{x} *+0.001303955 \mathrm{x}^{2 * *}$ & 0.12 & 0.34 \\
NSP & $91.45736421-3.35019444 \mathrm{x} *+0.05204282 \mathrm{x}^{2 * *}$ & 0.31 \\
SMP & $19.63407079-0.64781542 \mathrm{x} *+0.00926550 \mathrm{x}^{2 * *}$ & 0.71 \\
\hline
\end{tabular}


Table 3. Loads of morphological (group 1) and agronomic (group 2) characters in the canonical correlations (r) between the groups, in five spacing between sowing lines for soybean crop. Lagoa da Confusão - Tocantins State, Brazil, 2019.

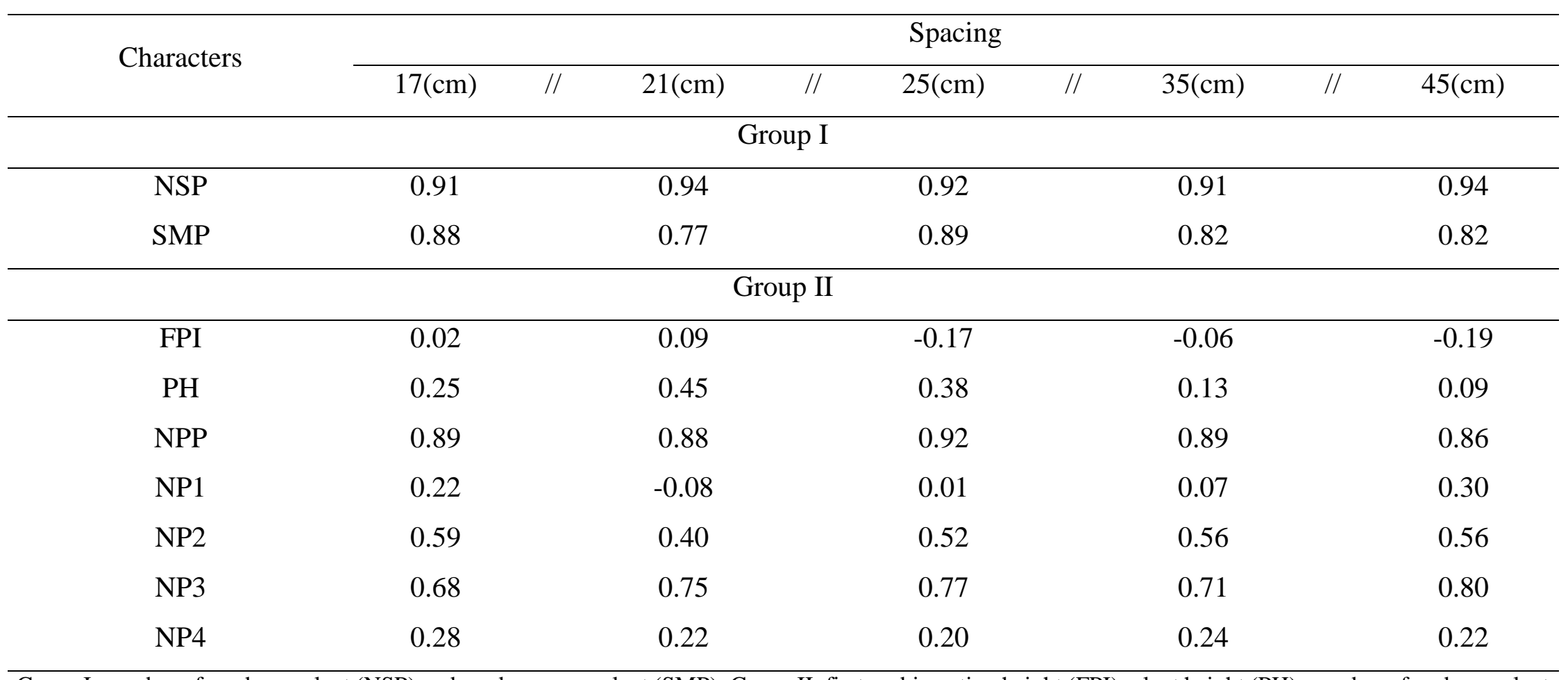

Group I: number of seeds per plant (NSP) and seed mass per plant (SMP); Group II: first pod insertion height (FPI); plant height (PH); number of pods per plant (NPP); number of pods with one grain (NP1); number of pods with two grains (NP2); number of pods with three grains (NP3) and number of pods with four grains (NP4). 
For Cruz et al., (2016), the increase in sowing density is positively correlated with soybean grain yield regardless of the spatial arrangement between plants. Studies by Werner et al., (2016) complement that the increase in the sowing rate from 150 to 560 thousand viable seeds per hectare increases the dry matter of the plant in the early stages of development and reduces the leaf/stem ratio of dry matter and the number of branches per plant. This information affirms the existing and dependent correlations regarding the arrangement of soybean plants in the field.

Studies carried out by Ivana et al., (2019) observed that the sowing density had an effect on the parameters number and nodular dry mass, root dry mass, as well as, in the final stand characters, plant height in maturation and grain yield. Thus, it is emphasized that, due to the increase in the population of plants in the same area, there will be greater competition between them, culminating in greater plant height, an increase in the levels of infestation by pests and diseases, since the greater amount of plants in the same space creates a microclimate that makes them more susceptible to an attack, requiring greater monitoring so that production is not affected.

The arrangement may also interfere as reported by Petter et al., (2016) in the dynamics of photosynthetically active radiation, reinforced by Werner et al., (2020) when commenting that the percentage of soil cover by the canopy of modern soybean cultivars, with type of indeterminate growth, are most affected by the spacing between rows at the beginning of the development cycle. Given these considerations, corroborating with Rocha et al., (2018) new experiments should be conducted by verifying the real responses of this new plant arrangement, taking into account the particularities of each producer.

\section{CONCLUSIONS}

The optimal arrangement for all variables analyzed was $30 \mathrm{~cm}$ between rows, demonstrating that it can be an interesting practice for sowing soybeans. It is noteworthy that the reduction in the spacing of the sowing line leads to an increase in costs and time of operation, which may render this recommendation unfeasible.

With the objective of carrying out two consecutive plantings in the rainy season, it causes the rural producer to neglect some agronomic practices that increase productivity, especially when they result from increased operational time. 


\section{REFERENCES}

CAMICIA, R. G. M.; MAGGI, M. F.; SOUZA, E. G.; BAZZI, C. L.; KONOPATZKI, E. A.; MICHELON, G. K.; PINHEIRO J. B. S. 2018. Productivity of soybean in management zones with application of different sowing densities. Ciência Rural, Santa Maria - RS. v. 48, n. 12. https://doi.org/10.1590/0103-8478cr20180532

CARVALHO, I. R.; SOUZA, V.Q.; NARDINO, M.; FOLLMANN, D.N.; SILVA, A.D.B.; SZARESKI, V. J.; PELEGRIN, A. J.; FERRARI, M.; OLIVOTO, T. 2015. Associação fenotípicas entre caracteres fisiológicos da soja contrastante ao hábito de crescimento. Gl. Sci Technol, Rio Verde, v.08, n.03, p.30 - 40, set/dez.

CRUZ, C. D. 2013. GENES a software package for analysis in experimental statistics and quantitative genetics. Acta Scientiarum. Maringá - PR. v.35, n.1, p.271-276,

CRUZ, S. C. S.; SENA JUNIOR, D. G.; SANTOS, D. M. A.; LUNEZZO, L.O.; MACHADO, C.G. 2016. Cultivo de soja sob diferentes densidades de semeadura e arranjos espaciais. Journal of Neotropical Agriculture, Cassilândia - MS. v. 3, n. 1, p. 1-6, 15 fev. https://doi.org/10.32404/rean.v3i1.431

FERRARI, M.; PELEGRIN, A. J.; SOUZA, V. Q.; NARDINO, M.; CARVALHO, I.R. 2014 Componentes de rendimento sob diferentes combinações de fungicidas e inseticidas em soja. Enciclopédia Biosfera, Jandaia - GO. Centro Científico Conhecer - Goiânia, v.10, n.19; p 19.

FOLLMANN, D.N., SOUZA, V.Q.; NARDINO, M.; CARVALHO, I.R.; DEMARI, G.H. 2014. Diferentes associações para aditivos em pré-semeadura na cultura da soja e seis efeitos sobre a qualidade das sementes produzidas. Enciclopédia Biosfera, Jandaia - GO. Centro Científico Conhecer - Goiânia, v.10, n.18; p, 1284 - 1292.

PETTER, F. A.; SILVA, J. A.; ZUFFO, A. M.; ANDRADE, F. R.; PACHECO, L. P.; ALMEIDA, F. A. 2016. Elevada densidade de semeadura aumenta a produtividade da soja? Respostas da radiação fotossinteticamente ativa. Bragantia, Campinas - SP. v. 75 , n. 2, p. 173-183, https://doi.org/10.1590/1678-4499.447

SILVA, A. D. B.; SOUZA, V. Q.; FOLLMANN, D.N.; NARDINO, M.; CARVALHO, I. R. 2015. Qualidade fisiológica de sementes de soja safrinha. Enciclopédia Biosfera, Jandaia - GO. Centro Científico Conhecer - Goiânia, v.11 n.21;

SZARESKI, V. J., SOUZA, V. Q., CARVALHO, I. R., NARDINO, M., FOLlMANN, D. N., DEMARI, G. H., FERRARI, M., OLIVOTO, T. 2015. Ambiente de cultivo e seus efeitos aos caracteres morfológicos e bromatológicos da soja. Revista Brasileira De Agropecuária Sustentável, Viçosa - MG 5(2). https://doi.org/10.21206/rbas.v5i2.247

WERNER, F.; SILVA. M. A. A.; FERREIRA, A. S.; NEUMAIER, N.; BALBINOT JUNIOR, A. A. 2020. Dinâmica da cobertura do solo por plantas e NDVI de cultivares de soja em diferentes arranjos espaciais de plantas. Colloquium Agrariae, Presidente Prudente - SP. v. 14, n. 2, p. 183-190, DOI: $10.5747 / \mathrm{ca} .2018$.

WERNER, F.; BALBINOT JUNIOR, A. A.; FERREIRA, A. S.; SILVA, M. A. A. DEBIASI, H. FRANCHINI, J. C. 2016. Soybean growth affected by seeding rate and mineral nitrogen. Revista Brasileira de Engenharia Agrícola e Ambiental, Campina Grande - PB. v. 20, n. 8, p. 126, https://doi.org/10.1590/1807-1929/agriambi.v20n8p734-738. 